\title{
How wide is the seismogenic zone of the Lesser Antilles forearc?
}

\section{Quelle est la largeur de la zone sismogène de l'avant-arc des Petites Antilles?}

\author{
Marc-André Gutscher ${ }^{1}$, Graham K. Westbrook ${ }^{2,4}$, Boris Marcaillou ${ }^{3}$, David Graindorge ${ }^{1}$, \\ Audrey Gailler ${ }^{1}$, Thibaud Pichot ${ }^{1,4}$, and René C. Maury ${ }^{1}$
}

\footnotetext{
1 Université de Brest, Université Européene de Bretagne, CNRS UMR6538 Laboratoire Domaines Océaniques, IUEM, Place N. Copernic, 29280 Plouzané, France.

2 School of Geography, Earth and Environmental Sciences, University of Birmingham, Edgbaston, Birmingham B15 2TT, UK.

${ }^{3}$ Université des Antilles et de la Guyane, Campus de Fouillole, BP 250, 97157 Pointe-à- Pitre, France.

4 Géosciences Marines, Ifremer Centre de Brest, BP 70, 29280 Plouzané, France.
}

\begin{abstract}
:
The Lesser Antilles subduction zone has produced no recent strong thrust earthquakes, making it difficult to quantify the seismic hazard from such events. The Lesser Antilles arc has a low subduction rate and an accretionary wedge that is very wide at its southern end. To investigate the effect of the wedge on seismogenesis, numerical models of forearc thermal structure were constructed along six transects perpendicular to the arc in order to determine the thermally predicted width of the seismogenic zone. The geometry of each section is constrained by published seismic profiles and crustal models derived from gravity and seismic data and by earthquake hypocenters at depth. A major constraint on the deep part of the model is that mantle temperature beneath the volcanic arc should achieve a temperature of $1,100^{\circ} \mathrm{C}$ to generate partial melts. Predicted surface heat flow is compared to the available heat flow observations. Thermal modeling results indicate a systematic southward increase in the width of the seismogenic zone, more than doubling in width from north to south and corresponding to a dramatic southward increase in forearc width (distance from the arc to the deformation front of the accretionary wedge). The minimum width of the seismogenic zone (distance between the intersections of the subduction interface with the $150^{\circ} \mathrm{C}$ and $350^{\circ} \mathrm{C}$ isotherms) increases from about $80 \mathrm{~km}$, north of $16^{\circ} \mathrm{N}$, to $230 \mathrm{~km}$, at $13^{\circ} \mathrm{N}$. The maximum width (between the $100^{\circ} \mathrm{C}$ and $450^{\circ} \mathrm{C}$ isotherms) ranges from about $150 \mathrm{~km}$ in the north to up to $320 \mathrm{~km}$ in the south. This large variation in the width of the seismogenic zone is a consequence of the increasing width of the accretionary wedge to the south, caused by the increased thickness of sediment on the subducting plate. There is good agreement between the thermally predicted seismogenic limits and the sparse distribution of recorded thrust earthquakes, which are observed only in the northern portion of the arc. Possible scenarios for mega-thrust earthquakes are discussed. Depending on the segment length (along-strike) of the rupture plane, the occurrence of an event of magnitude 8-9 cannot be excluded.
\end{abstract}

Keywords: Seismogenic zone ; Thrust earthquake ; Thermal modeling ; Accretionary wedge ; Lesser Antilles 


\section{Résumé :}

L'absence de grands séismes récents à mécanismes chevauchants dans la zone de subduction des Petites Antilles rend difficile l'évaluation de l'aléa sismique lié à de tels événements. L'arc des Petites Antilles est caractérisé par une faible vitesse de subduction et par la présence d'un prisme d'accrétion très développé à son extrémité méridionale. Afin d'évaluer les effets de la largeur de ce prisme sur la genèse des séismes, nous avons étudié six sections perpendiculaires à l'arc, du nord au sud de celui$\mathrm{ci}$, pour déterminer la largeur de la zone sismogène prédite par les modèles thermiques appliqués à chacune de ces coupes. La géométrie de ces dernières est contrainte par les profils sismiques publiés, par les modèles de structure crustale déduits des données gravitaires et sismiques, et enfin par la distribution des hypocentres des séismes. Un contrôle important permettant de tester la validité des modèles thermiques en profondeur est qu'une température minimale de $1100 \mathrm{oC}$, compatible avec la fusion partielle du manteau hydraté, doit être atteinte sous l'arc volcanique actif. Par ailleurs, le flux thermique en surface prédit par ces modèles doit être compatible avec les mesures de flux de chaleur. Les modèles thermiques retenus d'après ces critères montrent une augmentation du simple au double vers le sud de la largeur de la zone sismogène, qui correspond à un élargissement considérable de la taille du domaine avant-arc. En effet, la largeur minimale de la zone sismogène (définie comme la distance entre les intersections de l'interface des plaques avec les isothermes $150 \mathrm{o}$ et $350 \circ \mathrm{o}$ ) augmente d'environ $80 \mathrm{~km}$ au nord de $16 \mathrm{oN}$ jusqu'à $230 \mathrm{~km}$ à $13 \mathrm{oN}$. La largeur maximale de cette zone (définie par les intersections de l'interface avec les isothermes $100 \mathrm{o}$ et $450 \mathrm{oC}$ ) augmente, quant à elle, d'environ $150 \mathrm{~km}$ au nord jusqu'à $320 \mathrm{~km}$ au sud de l'arc. Cette variation considérable est la conséquence de l'augmentation de la largeur du prisme d'accrétion, elle-même causée par l'accumulation croissante des sédiments déposés sur la plaque plongeante. Les largeurs de la zone sismogène prédites à l'aide des modèles thermiques sont en bon accord avec les rares données disponibles sur les séismes à mécanismes chevauchants dans la partie nord de l'arc. Les scénarios possibles relatifs à des méga-séismes de ce type n'excluent pas de futurs événements atteignant des magnitudes de 8 à 9 .

Mots-clés : Zone sismogène ; Séisme chevauchant; Modélisation thermique ; Prisme d'accrétion ; Petites Antilles.

\section{Introduction}

Subduction megathrusts produce the largest earthquakes on earth (Ruff and Kanamori, 1980; Johnson et al., 1996; Stein and Okal, 2005). While many subduction zones (Tonga, Japan trench, etc.) produce frequent and large $(M>7)$ earthquakes, others are marked by long periods of relative quiescence, punctuated by great earthquakes (Goes, 1996; McCaffrey, 1997). The Antilles subduction zone spans over $1,500 \mathrm{~km}$ from NE South America to Puerto Rico, yet the vast majority of the Lesser Antilles forearc has not produced a significant subduction thrust type earthquake in the past 40 years. Indeed, according to the CMT Catalog, only two M5 earthquakes with a shallow west dipping focal mechanism have occured south of $16.5^{\circ} \mathrm{N}$ since 1976 (Fig. 1). However, strong historical earthquakes have struck the region (Martinique 1839, intensity IX ; and Guadeloupe 1843, intensity X) raising concern about its future seismic potential (Dorel, 1981; Bernard and Lambert, 1988). It has been difficult to quantify the seismic hazard in the region, because the dimensions of the seismogenic portion of the subduction fault plane cannot be determined using classical seismological methods

(source-time studies or aftershock studies of great earthquakes). This study applies numerical modeling of the Lesser Antilles fore-arc thermal structure, performed along six transects perpendicular to the arc in order to determine the thermally predicted limits of the seismogenic zone. These results are compared to the observed distribution of seismicity and to the few thrust type earthquakes known in this region. Calculations are then made with respect to scenarios of thrust earthquakes that could potentially occur here, in the future.

\section{The seismogenic zone}

Statistical studies of subduction zones worldwide suggest that the seismogenic portion of the plate boundary is situated between roughly $10 \mathrm{~km}$ and $40 \pm 5 \mathrm{~km}$ depth (Tichelaar and 
Ruff, 1993). The consensus view is that "seismogenic" (stick-slip) behavior along the subduction plate-boundary megathrust is rheologically controlled, by the pressure, temperature and lithology and fluid pressure of the rock units along the plate boundary. The locked or seismogenic portion of the fault plane is thus bounded by an updip limit and a downdip limit, with different mechanical processes controlling each.

For the downdip limit there are two main propositions. Some authors consider that elastic strain can accumulate only between the crystalline basement of the upper plate and the downgoing plate (Byrne et al., 1988; Ruff and Tichelaar, 1996), primarily because the mantle wedge beneath the upper plate is likely to be serpentinized (Hyndman et al., 1997; Oleskevich et al., 1999; Hilairet et al., 2007) and will thus exhibit stable sliding behavior. The second hypothesis is that as higher pressure and temperature conditions are reached (typically the $350^{\circ} \mathrm{C}$ and $450^{\circ} \mathrm{C}$ isotherms are considered to be the maximum temperatures for purely seismogenic and "transitional" behavior) the weakest rocks along the plate interface will begin to deform by ductile creep (Brace and Byerleee, 1970; Oleskevich et al., 1999). There is a broad consensus that felsic rocks hotter than $450^{\circ} \mathrm{C}$ are no longer capable of storing and releasing elastic energy (Scholz, 1990).

The updip limit is considered by most authors to be related to clay mineral dehydration reactions as high porosity deep-sea sediments are slowly transformed to low-grade metamorphic rocks that exhibit stick-slip behavior (Hyndman et al., 1995; Ruff and Tichelaar, 1996; Moore and Saffer, 2001). These dehydration reactions (illite to smectite and opal to quartz) begin at temperatures of $60-100^{\circ} \mathrm{C}$ and continue to about $150^{\circ} \mathrm{C}$ (Moore and Saffer, 2001). Thus, $150^{\circ} \mathrm{C}$ is considered by most workers to be the beginning of true stick-slip "seismogenic" behavior, with transitional behavior to about $100^{\circ} \mathrm{C}$ or perhaps lower (Hyndman et al., 1995; Oleskevich et al., 1999; Gutscher and Peacock, 2003; Marcaillou et al., 2006).

The simple conceptual model that interplate earthquake rupture can only occur along the contact zone between the oceanic crust of the downgoing plate and the crystalline crust of the upper plate (Byrne et al., 1988) has been disproved by the rupture zones of recent megathrust earthquakes in Sumatra 2004 (Lay et al., 2005), Chile 2010 (Vigny et al., 2011) and Japan (Simmons et al. 2011; Lay et al., 2011) where in all cases, rupture and thrust mechanism aftershocks extended to within $20 \mathrm{~km}$ of the trench. These examples clearly demonstrate that the updip limit of the seismogenic zone can extend beneath the deformed sediments of accretionary wedges for megathrust earthquakes. Concerning the downdip limit, the 2004 Sumatra earthquake in fact initiated along the subduction megathrust beneath the 
forearc mantle (Dessa et al., 2009; Klingelhoefer et al., 2010), further refuting this outdated model and underscoring the importance of finding other, better methods for estimating the limits of seismogenic ruptures beyond only studies of crustal structure.

In most subduction zones where strong earthquakes have occurred in the past few decades, source-time studies or aftershock studies can be used to determine the rupture zone and thus deduce the updip and downdip limits of the seismogenic zone (Beck and Ruff, 1984; Christensen and Beck, 1994; Lay et al., 2005, Simmons et al., 2011). In the absence of recent great earthquakes other "indirect" methods can be used to try to estimate the size of the potentially seismogenic zone. Geodetic methods for instance, were applied to try to determine the locked zone for Cascadia, which has not produced any great earthquakes in the past 300 years (Dragert et al., 1994 ; Miller et al., 2001; Wang et al., 2003). One of the most common indirect methods used to estimate the limits of seismogenic behavior, is numerical modeling of the temperature distribution along the plate interface, based on the rheological considerations discussed above. This method generally yields results that are in good agreement with other methods (source-time studies, distribution of aftershocks, geodetic studies) (Hyndman et al., 1995; Oleskevich et al., 1999; Gutscher and Peacock, 2003; Klingelhoefer et al., 2010).

\section{NUMERICAL MODELING OF FOREARC THERMAL STRUCTURE}

We used finite element (FE) software developed by Kelin Wang (Wang et al., 1995). The $500 \mathrm{~km}$ long FE-model consists of 936 quadrilateral elements, with a total of 2933 nodes. The model includes the effects of radiogenic heating in the crust, shear heating along the subduction interface for an effective shear stress increasing progressively over the first $40 \mathrm{~km}$ from 0 to $10 \mathrm{MPa}$, and corner flow in the mantle wedge (Peacock and Wang, 1999). Flow in the mantle wedge was obtained from the analytical solution for iso-viscous corner flow (Batchelor, 1967) driven by a subducting plate, a technique commonly used in numerical studies of forearc thermal structure (Peacock and Wang, 1999; Gutscher and Peacock, 2003; Klingelhoefer et al., 2010). Thermal conductivity in the mantle and oceanic crust is 3.138 W/mK consistent with the GDH1 model (Stein and Stein, 1992) and thermal conductivity in the sediments is $2.5 \mathrm{~W} / \mathrm{mK}$ (Peacock and Wang, 1999). Heat generation in the upper crust of the upper plate (the Caribbean plate) is 3.0 microWatt $/ \mathrm{m}^{2}$ and in the lower crust is 0.27 microWatt $/ \mathrm{m}^{2}$. Models with lower radioactive heat generation $\left(1.3 \mathrm{microWatt} / \mathrm{m}^{2}\right)$ resulted in nearly the same thermal structure at depth (along the plate interface), but predict a 
significantly lower surface heatflow than that observed in the arc and backarc region. Thus, the higher value was selected. The cooling effects of rapid sedimentation of the incoming sedimentary section were also evaluated and found to be negligible for the northern transects and to reduce heatflow by about $10 \%$ for the southern two transects (Ferguson et al., 1993). A low value of shear stress was used, increasing to $10 \mathrm{MPa}$ within $40 \mathrm{~km}$ from the deformation front, and thereafter remaining constant. These values are in good agreement with experimental work on the residual shear strength of clays in the context of the ODP drilling at the toe of the wedge (Kopf and Brown, 2003) and with ealier thermal modeling (Ferguson et al., 1993).

The geometry of the numerical model (the grid) as well as the principal boundary conditions are shown for a representative transect in Fig. 2. The three primary input parameters to the model are: the plate geometry, the age of the subducting lithosphere and the subduction velocity. The boundary conditions include: at the trench, oceanic lithosphere isotherms for a subducting oceanic plate of the appropriate age based on the GDH1 thermal cooling model (Stein and Stein, 1992), $0^{\circ} \mathrm{C}$ at the surface and an appropriate continental or oceanic geotherm on the backarc side boundary (depending on the nature of the upper plate). The age of the subducting oceanic lithosphere is known from magnetic anomaly studies (Westbrook, 1984; Klitgord and Schouten, 1986) and is approximately 80 Ma. The relative plate motion between the Caribbean and North American plates here is $2 \mathrm{~cm} / \mathrm{yr}$ along a N75E azimuth, on the basis of geodetic studies (DeMets et al., 2000; 2007). The relative motion between the Caribbean and South American plates is nearly E-W at a speed of $2 \mathrm{~cm} / \mathrm{yr}$ (Weber et al., 2001). These values were used as starting parameters for the thermal modeling.

The geometry of the subducting oceanic crust and the upper plate (down to $20-30 \mathrm{~km}$ depth) as well as the sedimentary thickness at the deformation front of the accretionary wedge is constrained by multi-channel seismic and wide-angle seismic data and gravity models (Speed et al., 1984; Westbrook et al., 1988; Bangs et al., 1990; Ferguson et al., 1993; Bangs et al., 2003; Christeson et al., 2003; Kopp et al., 2011) (Fig. 3). Sediment thicknesses on the incoming plate vary from as little as $500 \mathrm{~m}$ in the North to as much as $4-5 \mathrm{~km}$ in the South.

Six transects were modeled perpendicular to the Lesser Antilles arc, three with orientations of ENE-WSW, between $19^{\circ} \mathrm{N}$ and $16^{\circ} \mathrm{N}$ (Fig. 1, transects labeled A, B, C), and three with orientations E-W at latitudes $15^{\circ} \mathrm{N}, 14^{\circ} \mathrm{N}$, and $13^{\circ} \mathrm{N}$ (Fig. 1, transects labeled D, E, F). These orientations are chosen to be generally perpendicular to the arc and approximately parallel to the relative motion between the Caribbean plate and the two plates subducting beneath the Antilles (the oceanic portions of the North American and South American plates, 
respectively). For the Martinique transect, two orientations were chosen, one ENE-WSW, perpendicular to the arc and providing a shorter distance between the arc and the deformation front and one E-W, which is more representative of the kinematics between the South American plate (whose lithosphere descends beneath Martinique) and the Caribbean plate. Modeling both profiles provides an independent measure of the reliability of the thermal modeling and of the impact of the shallow geometry. The deeper geometry of the subducting slab is obtained from the distribution of hypocenters. Two different earthquake catalogs were examined, the global catalog of relocated events Jan. 1964 - Dec. 1995 (Engdahl et al., 1998), as well as the PDE/NEIC catalog ( http://neic.usgs.gov/neis/epic/epic.html ).

\section{OBSERVED SURFACE HEAT FLOW}

Heat flow data for the study area were obtained from the Global Heat Flow Database (http://www.heatflow.und.edu) and other published data (Fisher and Hounslow, 1990; Foucher et al. 1990; Langseth et al., 1990, Ferguson et al., 1993). The observed heatflow map (Fig. 4) shows a fairly high degree of scatter, but some general trends are discernable. In the mostly undeformed oceanic domain and frontal portion of the accretionary wedge, heatflow is generally low, with most values between $40-60 \mathrm{~mW} / \mathrm{m}^{2}$. Heat flow commonly reaches minimum values of $30-40 \mathrm{~mW} / \mathrm{m}^{2}$ in the fore-arc domain about $100 \mathrm{~km}$ from the arc and then increases to values above $100 \mathrm{~mW} / \mathrm{m}^{2}$ in the arc and back-arc region. The Grenada Basin (an Eocene back-arc basin) has a preponderance of heatflow values in the range $60-100 \mathrm{~mW} / \mathrm{m}^{2}$ and the Aves Ridge (believed to be a remnant arc) locally exhibits high heatflow values exceeding $150 \mathrm{~mW} / \mathrm{m}^{2}$. The upper plate (the Carribbean plate) is an oceanic plateau formed during the Cretaceous (Donnelly et al., 1990), which was thermally rejuvenated by arc magmatism and back-arc rifting, similar to the effects of a hotspot on oceanic lithosphere (Li et al., 2004). Thus, a young thermal age of 40 Ma was assigned to the upper plate lithosphere.

\section{THERMAL MODELING RESULTS: GUADELOUPE TRANSECT AND PARAMETER TESTS}

For all model transects a range of parameters were tested. We present the best-fit thermal model for the Guadeloupe transect (B) along with the range of acceptable models (Fig. 5). The expected heat flow at the surface is calculated for this set of thermal models 
(Fig. 5A) for the range of model parameters tested (Table 1). These included subduction velocities of 1, 2 and $3 \mathrm{~cm} / \mathrm{yr}$. Slab ages were varied from 60 to $100 \mathrm{Ma}$. Slab dips of $45^{\circ}$ and $53^{\circ}$ (for the deep portion 60-300 km depth) were also tested. Some models tested (for instance a slab dip of $45^{\circ}$, or a velocity of $1 \mathrm{~cm} / \mathrm{yr}$ ) were discarded because they predicted sub-arc temperatures too cold $\left(<1,000^{\circ} \mathrm{C}\right)$ below the volcanic arc to generate basaltic magmas (Schmidt and Poli, 1998) and are thus incompatible with the observed volcanic arc (Table 1). The preferred model, most consistent with the known slab age (80 Ma) and subduction velocity $(2 \mathrm{~cm} / \mathrm{yr})$, yields temperatures of $1,100^{\circ} \mathrm{C}$ under the arc.

The predicted heat flow calculated for the preferred model is $60 \mathrm{~mW} / \mathrm{m}^{2}$ at the deformation front, which is in fairly good agreement with the observed values (though somewhat higher than the average of the scattered data). A decline to about $30 \mathrm{~mW} / \mathrm{m}^{2}$ is predicted in the fore-arc, followed by an increase to $85 \mathrm{~mW} / \mathrm{m}^{2}$ in the arc and back-arc region. Regionally high heat flow observed in the Grenada Basin $\left(60-100 \mathrm{~mW} / \mathrm{m}^{2}\right)$ and Aves Ridge $\left(100-240 \mathrm{~mW} / \mathrm{m}^{2}\right)$ has been explained by previous workers in terms of the back-arc setting of the former and a probable origin as a remnant arc for the latter (Clark et al., 1978; Holcombe et al., 1990; Blackwell et al., 1991). The numerical model used does not account for heat advection by fluid flow, nor the heat transfer due to accretion of cold sediments at the toe of the accretionary wedge and thus certain short wavelength heat flow trends observed near the toe may not be successfully predicted by the thermal model.

We determined error bounds for the x-coordinates of the updip and downdip limits of the seismogenic zone for the Guadeloupe transect, with respect to the preferred model, on the basis of the parameter tests described above, and obtained $+15,-10 \mathrm{~km}$ for the $100^{\circ} \mathrm{C}$ isotherm, $+15,-5 \mathrm{~km}$ for the $150^{\circ} \mathrm{C}$ isotherm and $\pm 5 \mathrm{~km}$ for the $350^{\circ} \mathrm{C}$ isotherm. These are represented by the gray bars in Fig. 5B. The $450^{\circ} \mathrm{C}$ isotherm is controlled by the location of the nearby hot wedge of convecting asthenosphere and does not vary. However, uncertainty in the exact geometry of the convecting mantle wedge can be expected to affect the position of the $350^{\circ} \mathrm{C}$ and $450^{\circ} \mathrm{C}$ isotherms.

\section{SLAB DEPTH BELOW THE VOLCANIC ARC: EXPERIMENTAL AND GEOCHEMICAL CONSTRAINTS}

A peculiarity of the preferred model geometry described above is a depth to the slab below the volcanic arc, which is $120 \mathrm{~km}$. This is somewhat deeper than the global average of slab depth below volcanic arcs, reported to be $105 \mathrm{~km}$ on the basis of hypocenter distribution 
(Syracuse and Abers, 2006). Model geometries with a slab at $100 \mathrm{~km}$ depth below the arc were tested for the Guadeloupe transect (Fig. 5C) and for other transects as well. In all cases these models proved to be unsatisfactory, because the maximum temperature below the arc $\left(900^{\circ} \mathrm{C}\right)$ is too cold to explain the generation of basaltic magmas. The old age of the subducting slab makes its initial thermal structure rather cold, and the slow subduction velocity of $2 \mathrm{~cm} / \mathrm{yr}$ induces only very weak convective flow in the mantle wedge, and thus very limited advection of hot mantle to the sub-arc region (Fig. 4C).

Under these conditions, mantle temperatures of ca. $900^{\circ} \mathrm{C}$ are expected between depths of ca. 55 to $70 \mathrm{~km}$, corresponding to lithostatic pressures of 1.7 to $2.2 \mathrm{GPa}$. Conversely, temperatures higher than $1,000^{\circ} \mathrm{C}$ (up to $1,100^{\circ} \mathrm{C}$ ) are predicted to occur between 55 and $85 \mathrm{~km}$ (lithostatic pressures of 1.7 to $2.7 \mathrm{GPa}$ ) for a slab at $120 \mathrm{~km}$ depth (Fig. 5B). These conditions correspond to the generally accepted depths of genesis (or final equilibration with the mantle) of Lesser Antilles primary basaltic magmas $(50-90 \mathrm{~km}$; Macdonald et al., 2000).

Vapor-saturated partial melting of mantle wedge peridotites (i.e. melting in the presence of an $\mathrm{H}_{2} \mathrm{O}$-rich supercritical fluid likely derived from the dehydration of slab serpentinites, metabasalts and metasediments) begins at $940^{\circ} \mathrm{C}$ at $1.2 \mathrm{GPa}$, and the solidus temperature decreases continuously to $860^{\circ} \mathrm{C}$ at $2 \mathrm{GPa}$ and $800^{\circ} \mathrm{C}$ at $3.2 \mathrm{GPa}$ (Grove et al., 2006). Hovewer, in experimental studies, production of hydrous basaltic magmas (containing up to $10 \mathrm{wt} \% \mathrm{H}_{2} \mathrm{O}$ ) is only observed well above the solidus, for $3-15 \%$ melting rates, at temperatures consistently higher than $1,000^{\circ} \mathrm{C}$ (Grove et al., 2006). It is therefore unlikely to occur according to the thermal distribution modeled in Fig. 5C.

The abundance of amphibole-rich gabbroic cumulate xenoliths in Lesser Antilles magmas and the explosive character of their eruptions indicate their hydrous character (Macdonald et al., 2000). However, most of these magmas are andesitic to dacitic, and are thought to derive from open-system fractional crystallization of basaltic magmas in intracrustal magma reservoirs. Primitive (Mg-, Co-, $\mathrm{Cr}-$ and Ni-rich) basalts, in potential equilibrium with mantle peridotites, are uncommon at the surface: they occur in Grenada, St. Vincent and Ilet à Ramiers, Martinique (Maury et al., 1990). Detailed experimental petrology studies carried on St. Vincent basalts (Pichavant et al., 2002; Pichavant and Macdonald, 2003, 2007) show that the corresponding primary magmas contained up to 4.5-5.5 wt. $\% \mathrm{H}_{2} \mathrm{O}$. Their most magnesian olivine and clinopyroxene phenocrysts have typical mantle compositions, and the bulk melt containing 4.5 wt. $\% \mathrm{H}_{2} \mathrm{O}$ is in equilibrium with a spinel lherzolite assemblage at $1,185^{\circ} \mathrm{C}$ and $1.6 \mathrm{GPa}$ (Pichavant et al., 2002). At lower depths, it can evolve towards high- 
alumina basaltic melts containing $7-8$ wt. $\% \mathrm{H}_{2} \mathrm{O}$ at temperatures from 1,160 to $1,060^{\circ} \mathrm{C}$ (Pichavant and Macdonald, 2007). These conditions are totally inconsistent with the thermal distribution shown in Fig. 5C for a slab depth of $100 \mathrm{~km}$ beneath the volcanic arc. They are somewhat better accounted for by the $120 \mathrm{~km}$ depth model depicted in Fig. 5B. The latter model constructed for Guadeloupe, however, does not predict the maximal temperatures $\left(1,185-1,160^{\circ} \mathrm{C}\right)$ needed for the genesis of St. Vincent type hydrous primitive basalts. Conversely, the thermal structure obtained for the St. Vincent transect, predicts temperatures close to or slightly higher than $1,200^{\circ} \mathrm{C}$ at depths ranging from $70-90 \mathrm{~km}$, which are consistent with available experimental data. For the reasons given above, a slab depth of 100 $\mathrm{km}$ was discarded and all transects were modeled with a slab at $120 \mathrm{~km}$ depth beneath the arc.

The $120 \mathrm{~km}$ depth retained is in good agreement with the values reported for the depth to the slab below the Northern and Southern Antilles arc, $108 \mathrm{~km}$ and $122 \mathrm{~km}$, respectively (Table 1 Syracuse and Abers, 2006) and is in general agreement with hypocenter crosssections presented by other workers indicating a slab depth below the arc ranging from 120$140 \mathrm{~km}$ (Feuillet et al., 2002). Lastly, it should be noted that applying a temperaturedependent viscosity for calculating the corner flow in the mantle wedge, can be expected to yield higher temperatures below the arc for the same overall geometry (van Keken et al., 2002).

\section{THERMAL STRUCTURE AND THE SEISMOGENIC ZONE}

The modeled thermal structure along six transects is presented in Fig. 6 and the predicted and observed heatflow in Fig. 7. The updip limit (as defined by the $100-150^{\circ} \mathrm{C}$ isotherms) is located about $80-150 \mathrm{~km}$ from the trench for the northern three transects, where the sediment thickness is least $(<2 \mathrm{~km})$, and where the accretionary wedge is smallest $(<100$ $\mathrm{km}$ wide). For the transect $\mathrm{F}\left(\right.$ at $13^{\circ} \mathrm{N}$ ) with the largest thickness of incoming sediment (a total of $5 \mathrm{~km}$, including $3.5 \mathrm{~km}$ above the decollement), the $100^{\circ} \mathrm{C}$ and $150^{\circ} \mathrm{C}$ isotherms are crossed about $20 \mathrm{~km}$ and $80 \mathrm{~km}$ from the deformation front, respectively (Fig. $6 \mathrm{~F}$ ). Given the large sediment thicknesses, the thermal impact of sedimentation rates at the trench should also be considered (Marcaillou et al., 2008). Test model runs, including the effects of sedimentation rates varying from 1.0 to $2.7 \mathrm{~mm} / \mathrm{yr}$ (for a total incoming sediment thickness of $1500 \mathrm{~m}$ at the deformation front), were performed and showed only a minor effect on the thermal structure, producing a downdip shift of $\pm 5 \mathrm{~km}$ for the $150^{\circ} \mathrm{C}$ isotherm and a similarly small shift of $\pm 5 \mathrm{~km}$ for the $350^{\circ} \mathrm{C}$ isotherm. 
The position of the downdip limit, as defined by the $350^{\circ} \mathrm{C}$ and $450^{\circ} \mathrm{C}$ isotherms, is located about $60-80 \mathrm{~km}$ and 40-60 $\mathrm{km}$ from the volcanic arc, respectively. These isotherms are strongly controlled by the position of the convecting mantle corner. Although the exact geometry of the mantle corner is not well known, for similar slab dips, the corner can be expected to be located at a similar distance from the arc. For the two differently oriented Martinique transects $\mathrm{C}$ and D (Fig. 1, Fig. 6 C, D), where it is not obvious whether North America - Caribbean or South America - Caribbean motion is more appropriate, the deep thermal structure is nearly identical, with respect to the position of the volcanic arc. However, the shallow thermal structure is more strongly influenced by the different sedimentary thicknesses and the differences in the angle of plate dip here and results in a shift of the $150^{\circ} \mathrm{C}$ and $100^{\circ} \mathrm{C}$ isotherms by $20 \mathrm{~km}$ and $40 \mathrm{~km}$, respectively (Fig. $6 \mathrm{C}$, D). So summing up, the downdip limit is controlled primarily by the position of the convecting asthenospheric wedge when approaching the arc and the updip limit is controlled by the shallow crustal structure (plate dip and sediment thicknesses in the wedge and at the deformation front).

Specifically, our modeling predicts the minimum downdip width of the seismogenic zone (taking the $150^{\circ} \mathrm{C}$ and $350^{\circ} \mathrm{C}$ isotherms) to increase from $80 \mathrm{~km}$, north of $16^{\circ} \mathrm{N}$, to 230 $\mathrm{km}$ at $13^{\circ} \mathrm{N}$. The maximum width obtained for the seismogenic zone, including the transition zones $\left(100^{\circ} \mathrm{C}\right.$ and $450^{\circ} \mathrm{C}$ isotherms) ranges from about $140 \mathrm{~km}$ (north of $16^{\circ} \mathrm{N}$ ) to $320 \mathrm{~km}$ (at $\left.13^{\circ} \mathrm{N}\right)$. In all cases the horizontal uncertainty in the position of an isotherm is roughly $\pm 10 \mathrm{~km}$.

All available hypocenters for shallow earthquakes $(<50 \mathrm{~km}$ depth) with a shallow dipping thrust type earthquake mechanism were examined from the CMT catalog (Fig. 1) and projected onto the respective cross sections (black diamonds in Fig. 6). Thrust earthquakes are abundant for transect A (through Antigua) and become scarcer for transects B, C and D (through Guadeloupe and Martinique). In all three cases, however, the position in crosssection of these thrust earthquakes falls within the thermally predicted seismogenic zone, with most occuring between the $150^{\circ} \mathrm{C}$ and $350^{\circ} \mathrm{C}$ isotherms. For transect $\mathrm{A}$ (through Antigua) a few hypocenters project between the $150^{\circ} \mathrm{C}$ and $100^{\circ} \mathrm{C}$ isotherms, in the upper transition zone.

There is general agreement between the predicted surface heat flow and the in-situ observations (Fig. 7) where the latter are sufficiently abundant, but there are also numerous sources of discrepancy. First, short wavelength trends caused by tectonic thickening in the frontal portion of the accretionary wedge, are not accounted for by the model, such as the rapid decrease at the front of transect E (at $\left.14^{\circ} \mathrm{N}\right)$ (Fig. 7E), shown by numerous in-situ measurements and BSR observations (Ferguson et al., 1993). Second, there are other 
anomalously high heat-flow measurements due to fluid circulation through mud volcanoes, active faults (Fisher and Hounslow, 1990) or hydrothermal systems, locally causing a high degree of scatter in the observed heat flow (Fig. 7). Finally, there are insufficient heat-flow observations to constrain certain predicted trends in critical areas, in particular the arcward increase in heat flow, roughly $60-120 \mathrm{~km}$ seaward from the arc. This underscores the need for additional heat-flow measurements in this area, which should help to better constrain the location of the convecting corner and in turn the position of the downdip limit.

\section{POTENTIAL MAGNITUDE OF FUTURE SUBDUCTION EARTHQUAKES}

Taking the minimum dimensions for the seismogenic portion of the subduction fault plane for the northern Antilles region (transects A ad B through Antigua and Guadeloupe), i.e. a minimum E-W (downdip) width $=80 \mathrm{~km}$, and a taking a conservative (relatively short) $\mathrm{N}-\mathrm{S}$ lateral segment length of $100 \mathrm{~km}$, the seismic moment is calculated according to the equation:

$$
\begin{aligned}
& \mathrm{Mo}=\mu \mathrm{SD} \text {, with: } \\
& \mu=3 \times 10^{10} \mathrm{~Pa}, \\
& \text { rupture area } \mathrm{S}=8 \times 10^{9} \mathrm{~m}^{2} ; \\
& \text { for a slip of } \mathrm{D}=3 \mathrm{~m}: \\
& \mathrm{Mo}=7.2 \times 10^{20} \mathrm{Nm}, \\
& \mathrm{Mw}=2 / 3 \log \mathrm{Mo}-6.03, \text { yields } \mathrm{Mw}=7.9 .
\end{aligned}
$$

This is a slightly smaller size than the possible rupture zones of the 1839 and 1843 earthquakes (orange patches in Fig. 1). The co-seismic slip of $3 \mathrm{~m}$ (used in the above calculation) represents the potentially accumulated slip, for a fully locked subduction fault plane, considering a relative plate convergence rate of $2 \mathrm{~cm} / \mathrm{yr}$ over the past 150 years (since these last major earthquakes in the region). Such a magnitude does not seem unrealistic. Indeed the 1839 and 1843 earthquakes are likely to have had magnitudes in this range. The 1839 event was felt most strongly on Martinique with intensities of IX (modified Mercalli scale) and had an estimated magnitude between 7.5 and 8 (Dorel, 1981; Stein et al., 1982; Bernard and Lambert, 1988). The 1843 earthquake was even stronger, causing the most severe damage on Guadeloupe, with intensities up to $X$ and an estimated magnitude of roughly 8 (Dorel, 1981; Stein et al., 1982; Bernard and Lambert, 1988).

The above scenario is a conservative estimate. A more pessimistic scenario with a larger rupture area must also be considered. Taking the larger downdip width of 200-250 km obtained in the Barbados region (transects $\mathrm{E}$ and $\mathrm{F}$ at $14^{\circ} \mathrm{N}$ and $13^{\circ} \mathrm{N}$ ), and considering a longer lateral fault segment of $400-500 \mathrm{~km}$, extending from roughly $11^{\circ} \mathrm{N}$ to $15^{\circ} \mathrm{N}$, where no thrust earthquakes have occurred since at least 1976 (beginning of the CMT catalog) we 
obtain a much larger surface area, $\mathrm{S}=1.0 \times 10^{11} \mathrm{~m}^{2}$. For a uniform co-seismic slip of $3 \mathrm{~m}$ (representing 150 years of relative plate motion for a fully coupled plate interface), the seismic moment becomes Mo $=9.0 \times 10^{21} \mathrm{Nm}$. In this case the resulting magnitude is $\mathrm{Mw}=8$.6. If the last great earthquake in this zone occurred some 500 yrs ago (representing the period since Europeans arrived in the Antilles and began making written records), then more elastic strain may have accumulated, and the equivalent of $9 \mathrm{~m}$ of slip may be waiting to be released. In this case a magnitude 8.9 event cannot be excluded.

On the basis of the above calculations, it seems mechanically possible that magnitude 8-9 events could occur in the Antilles subduction zone. However, we have no reliable data on the recurrence interval between such earthquakes. Repeat times are likely to be longer than $150 \mathrm{yrs}$ and could be as much as several hundred years or more, like for instance in the NW Sumatra subduction zone (Monecke et al., 2008; Jankaew et al., 2008). Furthermore, the fault plane may not be fully locked (with $100 \%$ coupling), but a portion of the motion may be absorbed through aseismic slip or very slow (tremor type) slip (Rogers and Dragert, 2003; Beroza and Ide, 2009; Wech and Creager, 2011). Thus, while such estimates must be viewed with caution, they should serve as possible scenarios when selecting appropriate building codes and considering the installation of infrastructure in low-lying coastal areas that would be exposed to ground shaking and to the possible occurrence of strong tsunami induced by such a potential earthquake.

\section{DISCUSSION/CONCLUSIONS}

Among the best known examples of locked subduction fault planes with long periods of quiescence are the Nankai (SW Japan) and Cascadia subduction zones where $\mathrm{M}>8$ earthquakes occur on average at intervals ranging from about 150 years for Nankai (Kanamori, 1972; Hyndman et al., 1995) to several hundred to a thousand years for Cascadia (Satake et al., 1996; Goldfinger et al., 2003). The Lesser Antilles subduction zone shows numerous structural similarities to Cascadia, and Nankai (Gutscher and Westbrook, 2009) and to the NW Sumatra margin as well (Klingelhoefer et al., 2010). All four zones are marked by thick sedimentary accumulations at the "trench" (so much so that little or no morphological trench exists because the accretionary wedge has grown out beyond the flexural bulge in most cases) and all are characterized by a very broad, low-angle accretionary wedge, accumulated as these sediments were scraped off the seafloor (Westbrook et al., 1988; Moore et al., 1995; Klingelhoefer et al., 2010). The Antilles forearc, like Cascadia and Nankai, has not experienced a significant thrust type earthquake in the past 40 years. This was also the case for NW Sumatra prior to 2004 (Lay et al., 2005). And while the orthogonal plate convergence velocity is fairly slow (3-4 cm/yr) for Cascadia, Nankai and Sumatra, it is even slower (2 
$\mathrm{cm} / \mathrm{yr}$ ) for the Antilles, which suggests the recurrence interval may be even longer than for the other zones (Gutscher and Westbrook, 2009).

The modeling results presented here indicate a systematic southward increase in the width of the seismogenic zone, more than doubling in width from the northern Lesser Antilles to the south, in response to the southward increase in fore-arc width. The thermally predicted limits of seismogenic behavior are in good agreement with the distribution of thrust type earthquakes for the northern Antilles subduction zone. For the southern Antilles (south of $14.7^{\circ} \mathrm{N}$ ), thrust type earthquakes are absent (with a single exception at $12^{\circ} \mathrm{S}$ ), so it is not possible to confirm or to disprove the predictions of the thermal model. However, on the basis of its thermal and structural characteristics discussed here, we conclude the Lesser Antilles subduction zone is potentially capable of producing a magnitude 8 - 9 earthquake. 160 years have elapsed since the last great earthquakes and thus, if the fault plane is completely locked, it will have accumulated sufficient elastic strain to generate events of such strength. Given the higher population densities and their locations close to the coast, such an earthquake and an associated tsunami could have far more severe consequences than in the 19th century. However, the typical recurrence interval for great earthquakes here remains uncertain, and thus hampers an accurate assessment of seismic hazard. Paleoseismological studies such as dating of earthquake triggered turbidites and/or tsunami deposits, and identification and dating of markers of seismically induced vertical movements (beach terraces, corals) will be necessary to answer this important question.

Acknowledgments. - We thank Walter Roest for discussion of an earlier version of the manuscript and Kelin Wang for the use of his finite-element modeling code. We also thank the reviewers Claire Currie and Robert Harris for useful suggestions, which helped improve the manuscript.

\section{References}

Bangs N., Westbrook G.K., LAdD J.W. \& Buhl, P. (1990). - Seismic velocities from the Barbados Ridge Complex: indicators of high pore-fluid pressures in an accretionary wedge. - $J$. Geophys. Res., 95, 8767-8782.

Bangs N.L., Christeson G.L. \& ShiPLey T.H. (2003). - Structure of the Lesser Antilles subduction backstop and its role in a large accretionary system. - J. Geophys. Res., 108, 2358, doi10.1029/2002JB002040. 
BECK S.L. \& RUFF, L.J. (1984). - The rupture process of the great 1979 Colombia earthquake: Evidence for the asperity model. - J. Geophys. Res., 89, 9281-9291.

BERNARD P. \& LAMBERT, J. (1988). - Subduction and seismic hazard in the Northern Lesser Antilles: revision of the historical seismicity. - Bull. of Seismological Society of America, 78, 19651983.

BEROZA G.C. \& IDE S. (2009). - Deep tremors and slow quakes. - Science, 324, 1025-1026, doi: 10.1126/science.1171231.

Blackwell D.D., Steele J.L. \& CARTER L.S. (1991). - Heat flow patterns of the North American continent: A discussion of the DNAG Geothermal Map of North America, p. 423-437, in D.B. Slemmons, E.R. Engdahl, and D.D. Blackwell eds., Neotectonics of North America, Geological Society of America. DNAG Decade Map Volume 1, 498 p.

BRACE W.F. \& BYERLEE J.D. (1970). - California earthquakes : Why only shallow focus ? - Science, 168, $1573-1575$.

BouysSE P. \& WeSTERCAMP D. (1990). - Subduction of Atlantic aseismic ridges and Late Cenozoic evolution of the Lesser Antilles island arc. - Tectonophysics, 175, 349-380.

BYRNE D.E., DAVIS D.M. \& SYKES, L.R. (1988). - Loci and maximum size of thrust earthquakes and the mechanics of the shallow region of subduction zones. - Tectonics, 7, 833-857.

Christensen D.H. \& BeCK, S.L. (1994). - The rupture process and tectonic implications of the great 1964 Prince William Sound earthquake. - Pure Appl. Geophysics, 142, 29-53.

Christeson G.L., BAngs N.L. \& ShIPLEY T.H. (2003). - Deep structure of an island arc backstop, Lesser Antilles subduction zone. - J. Geophys. Res., 108, doi10.1029/2002JB002243.

Clark T.F., Korgen B.J. \& BeSt T.M. (1978). - Heat flow in the eastern Caribbean. - J. Geophys. Res., 83, 5883-5891.

DeMets C., Jansma P.E., Mattioli G.S., Dixon T.H., Farina F., Bilham R., Calais E. \& Mann, P. (2000). - GPS geodetic constraints on Caribbean-North America plate motion. - Geophysical Research Letters, 27, 437-440.

DeMets C., Mattioli G., Jansma P., Rogers R.D., Tenorio C. \& Turner H.L. (2007). - Present motion and deformation of the Caribbean plate: contraints from new GPS geodetic measurements from Honduras and Nicaragua. - Geological Society of America Special Paper 428, 21-36, doi: 10.1130/2007.2428(02).

Dessa J.-X., Klingelhoefer F., Graindorge D., Andre C., Permana H., Gutscher M.-A., Chauhan A., Singh S.C. and the SAGER-OBS Scientific Team (2009). - Megathrust earthquakes can nucleate in the fore-arc mantle: Evidence from the Great 2004 Sumatra event. - Geology, 37, 659-662, doi: 10.1130/G25653A.1 
Donnelly T.W., Beets D., CARR M.J., Jackson T., Klaver G., Lewis J., MAURy R.,

Schellenkens H., Smith A.L., Wadge G. \& Westercamp D. (1990). - History and tectonic setting of Caribbean magmatism, in Dengo, G., and Case, J.E., eds., The Caribbean region, The Geology of North America, Geological Society of America, Boulder, Colorado, v. H, ch. 13, p. 339-374.

DOREL J. (1981). - Seismicity and seismic gap in the Lesser Antilles arc and earthquake hazard in Guadeloupe. - Geophys. J. Roy. Astr. Soc., 67, 679-695.

Dragert H., Hyndman R.D., Rogers G.C. \& WANG K. (1994). - Current deformation and the width of the seismogenic zone of the northern Cascadia subduction thrust. - J. Geophys. Res., 99, 653-668.

ENGDAHL E.R., VAN DER HILST R.D. \& BULAND R. (1998). - Global teleseismic earthquake relocation with improved travel times and procedures for depth relocation. - Bull. Seism. Soc. Am., 88, $722-743$.

Ferguson I.J., Westbrook G.K., LAngSeth M.G. \& Thomas G.P. (1993). - Heat flow and thermal models of the Barbados ridge accretionary complex. - J. Geophys. Res., 98, 4121-4142.

Feuillet N., MANighetTi, I., TAPPONNIER, P. \& JACQUes E. (2002). - Arc parallel extension and localization of volcanic complexes in Guadeloupe, Lesser Antilles. - J. Geophys. Res., 107, (B12), doi:10.1029/2001JB000308.

Fisher A.T. \& HounsLow M.W. (1990). - Heat flow through the toe of the Barbados accretionary complex. In Moore, J.C., Mascle, A., et al., Proceedings of the Ocean Drilling Program, Scientific Results, 110, College Station, Texas, 345-363.

Foucher J.P., Le Pichon X., Lallemant S., Hobart M.A., Henry P., Benedetti M., Westbrook G.K. \& LANGSETH M. (1990). - Heat flow, tectonics and fluid circulation at the toe of the Barbados Ridge accretionary prism. - J. Geophys. Res., 95, 8859-8868.

GOES S. (1996). - Irregular recurrence of large earthquakes: an analysis of historic and paleoseismic catalogs. - J. Geophys. Res., 101, 5739-5749.

Goldfinger C., Nelson C.H., Johnson J.E. \& Shipboard Scientific Party (2003). - Holocene earthquake records from the Cascadia subduction zone and northern San Andreas Fault based on precise dating of offshore turbidites. - Ann. Rev. Earth Planet. Sci., 31, 555-577.

Grove T.L., Chatterjee N., Parman S.W. \& Médard E. (2006). - The influence of $\mathrm{H}_{2} \mathrm{O}$ on mantle wedge melting. - Earth and Planetary Science Letters, 249, 74-89.

Gutscher M.-A. \& PEACOcK S.M. (2003). - Thermal models of flat subduction and the rupture zone of great subduction earthquakes. - J. Geophys. Res., 108 (B1), doi:10.1029/2001JB000787. 
Gutscher M.-A. \& Westbrook G.K. (2009). - Great earthquakes in slow-subduction low-taper margins. In Subduction Zone Geodynamics, (eds. S. Lallemand, F. Funiciello) Frontiers in Earth Sciences, Springer, Berlin, 119-133.

Hilairet N., Reynard B., Wang Y., Daniel I., Merkel S., Nishiyama N. \& Petitgirard S. (2007). - High-Pressure creep of serpentine, interseismic deformation, and initiation of subduction. - Science, 318, no. 5858, 1910 - 1913, doi: 10.1126/science.1148494.

Holcombe T.L., Ladd J.W., Westbrook G., Edgar N.T. \& Bowland, C.L. (1990). - Caribbean marine geology; Ridges and basins of the plate interior, in Dengo, G., and Case, J.E., eds., The Caribbean region, The Geology of North America, Geological Society of America, Boulder, Colorado, v. H, ch. 9, 231-260.

HYNDMAN R.D., YAMANO M. \& WANG K. (1995). - Thermal constraints on the seismogenic portion of the southwestern Japan subduction thrust. - J. Geophys. Res., 100, 15373-15392.

Hyndman R.D., Yamano M. \& OleskeVich D.A. (1997). - The seismogenic zone of subduction thrust faults. - Island Arc, 6, 244-260.

Jankaew, K., Atwater, B.F., Sawai, Y., Choowong, M., Charoentitirat, T., Martin, M.E. \& Prendergast, A. (2008). - Medieval forewarning of the 2004 Indian ocean tsunami in Thailand. - Nature, 455, doi:10.1038/nature07373.

Johnson J.M., Satake K., Holdahl S.R. \& SAuber J. (1996). - The 1964 Prince William Sound earthquake: Joint inversion of tsunami and geodetic data. - J. Geophys. Res., 101, 1496514991.

KANAMORI H. (1972). - Tectonic implications of the 1944 Tonankai and 1946 Nankaido earthquakes. - Phys. Earth Planet. Inter., 5, 129-139.

Klingelhoefer F., Gutscher M.-A., Ladage S., Dessa J.-X., Graindorge D., Franke D., Andre C., Permana H., Yudistira T. \& Chauhan A. (2010). - Limits of the seismogenic zone in the epicentral region of the 26 Dec. 2004 Great Sumatra-Andaman earthquake: results from seismic refraction and wide-angle reflection surveys and thermal modeling. - J. Geophys. Res., 115, B01304, doi :10.1029/2009JB006569.

Klitgord K.D. \& Schouten H. (1986). - Plate kinematics of the central Atlantic. In Vogt, P.R. and Tucholke, B.E. eds., The Geology of North America, Volume M, The Western North Atlantic Region: Geol. Soc. Amer, 351-378.

KOPF A. \& BROWN K.M. (2003). - Friction experiments on saturated sediments and their implications for the stress state of the Nankai and Barbados subduction thrusts. - Mar. Geology, 202, 193210. 
Kopp H., Weinzierl W., Becel A., Charvis P., Evain M., Flueh E.R., Gailler A., Galve A., Hirn A., Kandilarov A., Klaeschen D., Laigle M., Papenberg C., Planert L., Roux E. \& Trail and Thales teams (2011). - Deep structure of the central Lesser Antilles Island Arc: Relevance for the formation of continental crust. - Earth and Planetary Science Letters, 304, 121-134, doi: 10.1016/j.eps1.2011.01.024.

Langseth M.G., Westbrook G.K. \& Hobart M. (1990). - Contrasting geothermal regimes of the Barbados Ridge accretionary complex. - J. Geophys. Res., 95, 8829-8843.

Lay T., Kanamori H., Ammon C.J., Nettles M., Ward S.N., Aster R.C., Beck S.L., BileK S.L., Brudzinski M.R., Butler R., DeShon H.R., Ekstrom G., SATAKe J. \& SiPkin S. (2005). The Great Sumatra-Andaman earthquake of 26 December 2004. - Science, 308, 1127-1133.

Lay T., Ammon C.J., KANAmori H., Xue L. \& Kim M.J. (2011). - Possible large near-trench slip during the great 2011 Tohoku (Mw9.0) earthquake. - Earth Planets and Space, 63, doi:10.5047/eps.

Li X., KIND R., YUAN X., WÖLBERn I. \& HANKA W. (2004). - Rejuvenation of the lithosphere by the Hawaiian plume. - Nature, 427, 827-829, doi:10.1038/nature02349.

Macdonald R., Hawkesworth C.J., \& HeAth E. (2000). - The Lesser Antilles volcanic chain: a study in arc magmatism. - Earth-Science Reviews, 49, 1-76.

Marcaillou B., Spence G., Collot J.-Y. \& Wang K. (2006). - Thermal regime from bottom simulating reflectors along the north Ecuador-south Colombia margin: Relation to margin segmentation and great subduction earthquakes. - J. Geophys. Res., 111, B12407, doi:10.1029/2005JB004239.

Marcaillou B., Spence G., Wang K. \& Collot J.-Y. (2008). - Thermal segmentation along the N. Ecuador-S. Colombia margin (1-4 degrees N): Prominent influence of sedimentation rate in the trench, Earth Planet. Sci. Lett., 272, 296-308, doi:10.1016/j.eps1.2008.04.049.

Maury R.C., Westbrook G.K., BaKer P.E., Bouysse P. \& Westercamp D. (1990). - Geology of the Lesser Antilles. In: Dengo, G. and Case, J.E. (eds), The Caribbean region: The Geology of North America, Geological Society of America, Boulder, Colorado, v. H, ch. 5, 141-166.

MCCAFFREY R. (1997). - Influences of recurrence times and fault zone temperatures on the age-rate dependence of subduction zone seismicity. - J. Geophys. Res., 102, 22839-22854.

Miller M.M., Johnson D.J., Rubin C.M., Dragert H., WAng K., QAMAR A. \& Goldfinger C. (2001). - GPS-determination of along-strike variation in Cascadia margin kinematics: Implications for relative plate motion, subduction zone coupling, and permanent deformation. - Tectonics, 20, 161-176. 
Monecke, K., Finger, W., Klarer, D., Kongko, W., McAdoo, B.G., Moore, A.L. \& Sudrajat, S.U. (2008). - A 1,000-year sediment record of tsunami recurrence in northern Sumatra. Nature, 455, doi:10.1038/nature07374.

MoORE J.C. \& SAFFER D. (2001). - Updip limit of the seismogenic zone beneath the accretionary prism of southwest Japan: an effect of diagenetic to low-grade metamorphic processes and increasing effective stress. - Geology, 29, 183-186.

Moore J.C., SHIPLEY T.H. \& 26 others (1995). - Abnormal fluid pressures and fault-zone dilation in the Barbados accretionary prism: Evidence from logging while drilling. - Geology, 23, 605608.

Oleskevich D.A., Hyndman R.D. \& WAng K. (1999). - The updip and downdip limits to great subduction earthquakes: Thermal and structural models of Cascadia, south Alaska, SW Japan, and Chile. - J. Geophys. Res., 104, 14,965-14,991.

Patriat M., Pichot, T., Westbrook, G.K., Umber, M., Deville, E., Benard, F., Roest, W.R. \& LOUBRIEU, B. (2011). - Evidence for Quaternary convergence across the North America-South America plate boundary zone, east of the Lesser Antilles. - Geology, 39, 979-982, doi: 10.1130/G32474.1.

PEACOCK S.M. \& WANG K. (1999). - Seismic consequences of warm versus cool subduction zone metamorphism: Examples from northeast and southwest Japan. - Science, 286, 937-939.

PichaVAnt M. \& MaCDONALD R. (2003). - Mantle genesis and crustal evolution of primitive calcalkaline basaltic magmas from the Lesser Antilles arc. In: Larter, R.D. and Peat, P.T. (eds), Intra-oceanic subduction systems: tectonic and magmatic processes. Geological Society, London, Special Publication, 219, 239-254.

PichaVAnT M. \& MACDONALD R. (2007). - Crystallization of primitive basaltic magmas at crustal pressures and genesis of the calc-alkaline igneous suite: experimental evidence from $\mathrm{St}$ Vincent, Lesser Antilles arc. - Contributions to Mineralogy and Petrology, 154, 535-558. Pichavant M., Mysen B.O. \& Macdonald R. (2002). - Source and $\mathrm{H}_{2} \mathrm{O}$ content of high-MgO magmas in island arc settings: an experimental study of a primitive calc-alkaline basalt from St Vincent, Lesser Antilles arc. - Geochimica et Cosmochimica Acta, 66, 2193-2209.

Rogers G. \& Dragert H. (2003). - Episodic tremor and slip on the Cascadia subduction zone: The chatter of silent slip. - Science, 300, no. 5627, 1942 - 1943, doi: 10.1126/science.1084783.

RUFF L. \& KANAMORI H. (1980). - Seismicity and the subduction process. - Phys. Earth Planet. Inter., 23, 240-252. 
RUFF L.J. \& TiCHELAAR B.W. (1996). - What controls the seismogenic plate interface in subduction zones? in Subduction: Top to Bottom, ed. by G.E. Bebout, D.W. Scholl, S.H. Kirby and J. Platt, Geophysical Monograph 96, AGU,105-111.

SAtAKe K., Shimazaki K., Tsuji Y. \& UedA K. (1996). - Time and size of a giant earthquake in Cascadia inferred from Japanese tsunami records of January 1700. - Nature, 379, 246-249. SCHMIDT M.W. \& Poli S. (1998). - Experimentally based water budgets for dehydrating slabs and consequences for arc magma generation. - Earth Planet. Sci. Lett., 163, 361-379.

Scholz C.H. (1990). - The Mechanics of Earthquakes and Faulting, Cambridge Univ. Press, Cambridge, 439 p.

Screaton E.J., Fisher A.T., CARson B. \& Becker K. (1997). - Barbados Ridge hydrogeologic tests: Implications for fluid migration along an active decollement. - Geology, 25, 239-242.

Simons M., Minson S.E., Sladen A., Ortega F., Jiang J., Owen S.E., Meng L., Ampuero J.P., Wei S., Chu R., Helmberger D.V., Kanamori H., Hetland E., Moore A.W. \& Webb F.H. (2011). - The 2011 magnitude 9.0 Tohoku-oki earthquake: Mosaicking the megathrust from seconds to centuries. - Science, 332, 1421, doi: 10.1126/science.1206731.

Speed R., Westbrook G.K., Biju-Duval B., Ladd J.W., Mascle A., Moore J.C., Saunders J.B., SCHOONMAKER J.E. \& STEIN S. (1984). - Lesser Antilles arc and adjacent terranes. Atlas 10, Ocean Margin Drilling Program, Regional Atlas Series, Marine Science International, Woods Hole, 27 sheets.

Stein S., Engeln J.F., Wiens D.A., Fujita K. \& Speed R.C. (1982). - Subduction seismicity and tectonics in the Lesser Antilles arc. - J. Geophys. Res., 87, 8642-8664.

STEIN C.A. \& STEIN S. (1992). - A model for the global variation in oceanic depth and heat flow with lithospheric age. - Nature, 359, 123-126.

SteIn S. \& OKAL E.A. (2005). - Speed and size of the Sumatra earthquake. - Nature, 434, 581-582.

SYRACUSE E.M. \& ABERS G.A. (2006). - Global compilation of slab depth beneath arc volcanoes and implications. - Geochemistry, Geophysics, Geosystems, 7, doi :10.1029/2005GC001045.

TichelaAR B.W. \& RUfF L.J. (1993). - Depth of seismic coupling along subduction zones. - $J$. Geophys. Res., 98, 2017-2037.

UPSHALl H.G. (1991). - The structure of the northern Lesser Antilles accretionary complex. Unpublished PhD thesis, University of Birmingham, $176 \mathrm{p}$.

VAN KeKen, P., KIEFER, B. \& PEACOCK, S.M. (2002). High-resolution models of subduction zones: implications for mineral dehydration reactions and the transport of water into the deep mantle, Geochem., Geophys. Geosyst., v.3, doi: 10.1029/2001GC000256. 
Vigny C., Socquet A., Peyrat S., Ruegg J.C., Métois M., Madariaga R., Morvan S., Lancieri M., Lacassin R., Campos J., Carrizo D., Bejar-Pizarro M., Barrientos S., Armijo R., Aranda C., Valderas-Bermejo M.C., Ortega I., Bondoux F., Baize S., Lyon-Caen H., Pavez A., Vilotte J.P., Bevis M., Brooks B., Smalley R., Parra H., Baez J.C., Blanco M., Cimbaro S., \& Kendrick E. (2011). - The 2010 Mw8.8 Maule megathrust earthquake of Central Chile, monitored by GPS. - Science, 332, 6036, 1417-1421, doi:10.1126/science.1204132.

WANG K.L., HYNDMAN R.D. \& YAMANO M. (1995). - Thermal regime of the southwest Japan subduction zone - effects of the age history of the subducting plate. - Tectonophysics, 248, 5369.

Wang K., Wells R, Mazzotti S, Hyndman R.D. \& SagiYa T. (2003). - A revised dislocation model of interseismic deformation of the Cascadia subduction zone. - J. Geophys. Res., 108, 2026, doi:10.1029/2001JB001227.

Weber J.C, Dixon T.H., DeMets C., Ambeh W.B., Jansma P., Mattioli G., SAleh J., Sella G., Bilham R. \& PEREZ O. (2001). - GPS estimate of the relative motion between the Caribbean and South American plates, and geologic implications for Trinidad and Venezuela. - Geology, 29, 75-78.

WeCh A.G. \& CREAGER K.C. (2011). - A continuum of stress, strength and slip in the Cascadia subduction zone. - Nature Geoscience, 4, 624-628, doi:10.1038/ngeo1215.

WESTBROOK G.K. (1975). - The structure of the crust and upper mantle in the region of Barbados and the Lesser Antilles. - Geophys. J. R. Astr. Soc., 43, 201-242.

Westbrook G.K. (1984). - Magnetic lineations and fracture zones, in Speed R.C., Westbrook G.K. and other eds., Lesser Antilles arc and adjacent terranes, Atlas 10 Ocean Margin Drilling Program, Regional Atlas Series. Marine Science International, Woods Hole, MA.

Westbrook G.K. \& MCCANN W.R. (1986). - Subduction of Atlantic lithosphere beneath the Caribbean. In: Vogt, P.R. and Tucholke, B.E. eds., The Geology of North America, Volume M, The Western North Atlantic Region: Geol. Soc. Amer, 341-350.

Westbrook G.K., LAdD J.W., Buhl P., BAngs N. \& Tiley G.J. (1988). - Cross section of an accretionary wedge: Barbados Ridge complex. - Geology, 16, 631-635. 


\section{Figure Captions:}

FIG. 1. - Regional map of the Lesser Antilles arc, with relief (Gebco 1 min grid, IOC) seismicity (PDE/NEIC Catalog M>4 1973-2008, circles scaled according to magnitude) and shallow thrust type earthquake focal mechanisms CMT Catalog. The sampling boxes for the seismicity cross-sections the co-located thermal models from Figure 6 are indicated (black lines), as well as the position of the seismic profiles shown in Figure 3 (magenta lines) used to constrain the deep structure. The estimated locations of the two strongest historical earthquakes in the area, 1839 (maximum intensities IX), and 1843 (maximum intensities X), both believed to have been subduction thrust type events (Dorel, 1981; Stein et al., 1982; Bernard and Lambert, 1988) are shown as light orange ellipse shaped patches. The thick green dashed lines indicate the positions of the $150^{\circ} \mathrm{C}$ and $350^{\circ} \mathrm{C}$ isotherms along the subduction fault plane obtained from the thermal modeling described below, while the thinner green dashed lines indicate the $100^{\circ} \mathrm{C}$ and $450^{\circ} \mathrm{C}$ isotherms. The aseismic ridges appear to mark a diffuse plate boundary between the North and South American plates (Bouysse and Westercamp, 1990; Patriat et al., 2011).

FIG. 1. - Carte de l'arc des Petites Antilles, associant données bathymétriques (grille Gebco 1 min., IOC) hypocentres de séismes (catalogue PDE/NEIC, séismes M>4 1973-2008, taille des cercles proportionnelle à la magnitude) et mécanismes au foyer des séismes superficielles chevauchants (catalogue CMT). Les zones retenues pour la détermination des coupes de sismicité et le calcul des modèles thermiques correspondants (Fig. 6) sont délimitées en noir, de même que la position des profils sismiques (Fig. 3), en magenta, utilisés pour contraindre la structure profonde. Les positions estimées des deux principaux séismes historiques, 1839 (intensité IX) et 1843 (intensité X), considérés comme liés au plan de faille de subduction (Dorel, 1981; Stein et al., 1982; Bernard et Lambert, 1988) sont indiquées par des ellipses en orange. Les épaisses lignes vertes en pointillées indiquent la position des isothermes $150^{\circ} \mathrm{C}$ et $350^{\circ} \mathrm{C}$ sur le long du plan de faille de subduction, tandisque les lignes vertes pointillés plus fines, montrent les isothermes de $100^{\circ} \mathrm{C}$ et $450^{\circ} \mathrm{C}$. Les rides asismiques semblent marquer une limite diffuse entre les plaques Amérique du Nord et Amérique du Sud (Bouysse and Westercamp, 1990 ; Patriat et al., 2011).

FIG. 2. - An example of the geometry of one of the finite element grids (Guadeloupe transect), showing the different lithospheric units and the boundary conditions imposed on the model. The actual model size is $505 \mathrm{~km}$ (horizontally) x $500 \mathrm{~km}$ (vertically), with 936 elements (at a horizontal spacing of $20 \mathrm{~km}$ ) defined by 2933 nodes.

FIG. 2. - Géométrie de l'un des modèles numériques montrant la grille d'éléments finis (section Guadeloupe), illustrant les différentes unités lithosphériques et les conditions aux limites imposées au modèle. La taille de celui-ci est de $505 \mathrm{~km}$ (horizontalement) sur $500 \mathrm{~km}$ (verticalement), avec 936 éléments (espacement horizontal de 20 km) définis par 2933 noeuds.

FIG. 3. - The shallow geometry of the Lesser Antilles subduction zone as constrained by multi-channel and wide-angle seismic data and by gravity models A) Antigua transect (Westbrook and McCann, 1986 - gravity and seismic refraction model; Upshall, 1991 seismic reflection section) B) Structural section south of Guadeloupe based on wide-angle and 
multi-channel seismic data (Kopp et al., 2011) C) 16²0' $\mathrm{N}$ transect (Westbrook et al., 1988) D) $14^{\circ} 20^{\prime} \mathrm{N}$ transect (Ferguson et al., 1993) E) $13^{\circ} \mathrm{N}$ transect (Speed et al., 1984).

FIG. 3. - Géométrie superficielle de la zone de subduction des Petites Antilles, d'après les données de sismique multi-traces et grand angle ainsi que les modèles gravitaires. A) section d'Antigua (Westbrook and McCann, 1986 - gravité et sismique réfraction ; Upshall, 1991 sismique réflexion) ; B) section sismique au sud de la Guadeloupe basée sur des données grand-angle et multi-traces ((Kopp et al., 2011); C) section à 16 $20^{\circ} \mathrm{N}$ (Westbrook et al., 1988) ; D) section à $14^{\circ} 20^{\prime} \mathrm{N}$ (Ferguson et al., 1993) ; E) section à $13^{\circ} \mathrm{N}$ (Speed et al., 1984).

FIG. 4. - Regional map of observed surface heatflow obtained from the following sources: (Global Heatflow Database; Langseth et al., 1990; Fisher and Hounslow, 1990; Ferguson et al., 1993) with sampling boxes for heatflow sections presented in Fig. 7 shown.

FIG. 4. - Carte régionale du flux de chaleur observé (Global Heatflow Database; Langseth et al., 1990; Fisher et Hounslow, 1990; Ferguson et al., 1993). Les zones retenues pour les coupes de la Fig. 7 sont indiquées.

FIG. 5. - Results of numerical modeling for Guadeloupe transect A) Observed surface heat flow (red circles) and modelled surface heat flow for a range of subduction parameters as indicated. The gray shading shows the range of acceptable models and the thick black line the heat flow predicted by the preferred model ( $\mathrm{v}=2 \mathrm{~cm} / \mathrm{yr}$; slab age $80 \mathrm{Ma}$, slab dip $\left.53^{\circ}\right)$. B) Thermal structure along the Guadeloupe transect obtained by finite-element modeling $\left(100^{\circ} \mathrm{C}\right.$ isotherms), with earthquake hypocenters projected (see sampling box in Fig. 1) and slab depth of $120 \mathrm{~km}$ below the volcanic arc. The thermally predicted limits of the seismogenic zone are shown. The gray zones indicate the range of uncertainty on the basis of the model parameters tested (see text). The updip limit is given by the $150^{\circ} \mathrm{C}$ isotherm (with a transition zone to the $100^{\circ} \mathrm{C}$ isotherm). The downdip limit is given by the $350^{\circ} \mathrm{C}$ isotherm (with a transition zone to the $450^{\circ} \mathrm{C}$ isotherm). C) Thermal structure obtained along the Guadeloupe transect for a slab dip of $45^{\circ}$ and a slab depth of $100 \mathrm{~km}$ below the volcanic arc. The resulting temperature beneath the $\operatorname{arc} \leq 900^{\circ} \mathrm{C}$ ) is too cold to allow generation of basaltic magmas, and this model must be discarded.

FIG. 5. - Résultats de la modélisation numérique pour la section Guadeloupe. En A), le flux de chaleur observé en surface (cercles rouges) et celui calculé pour différentes valeurs des paramètres de la subduction sont comparés. Les niveaux de gris indiquent la gamme des modèles acceptables et la ligne noire épaisse le flux de chaleur prédit par le modèle retenu $\left(v=2 \mathrm{~cm} / a n\right.$; âge de la plaque plongeante $80 \mathrm{Ma}$, pendage $\left.53^{\circ}\right)$. B) Structure thermique de la section Guadeloupe obtenue par les modèles à éléments finis (isothermes tous les $100^{\circ} \mathrm{C}$ ), montrant la localisation des foyers des séismes (de la zone indiquée en Fig. 1) pour une plaque plongeante située à $120 \mathrm{~km}$ sous l'arc volcanique actif. Les limites de la zone sismogène prédites par les modèles thermiques sont indiquées. Les zones grises indiquent la gamme d'incertitude en fonction des paramètres testés du modèle. La limite supérieure correspond à l'isotherme $150^{\circ} \mathrm{C}$ (avec une zone de transition jusqu'à l'isotherme $100^{\circ} \mathrm{C}$ ). La limite inférieure correspond à l'isotherme $350^{\circ} \mathrm{C}$ (avec une zone de transition jusqu'à l'isotherme $450^{\circ} \mathrm{C}$ ). C) Structure thermique de la section Guadeloupe obtenue pour une plaque plongeant à $45^{\circ}$ et située à $100 \mathrm{~km}$ sous l'arc volcanique actif. La température sous 
celui-ci $\left(\leq 900^{\circ} \mathrm{C}\right)$ est trop faible pour permettre la genèse de magmas basaltiques, et le modèle correspondant n'est pas retenu.

FIG. 6. - Forearc thermal structure along six transects obtained by finite-element modelling $\left(100^{\circ} \mathrm{C}\right.$ isotherms), with earthquake hypocenters projected (see sampling box in Fig. 1). The thermally predicted limits of the seismogenic zone are shown. A) Antigua B) Guadeloupe, C) Martinique NW-SE, D) Martinique E-W, E) St. Lucia / N Barbados Ridge and F) St. Vincent / Barbados. The resulting minimum downdip width obtained ranges from $80 \mathrm{~km}$ (north of $16^{\circ} \mathrm{N}$ ) to $230 \mathrm{~km}$ at $13^{\circ} \mathrm{S}$ (measuring from the $150^{\circ} \mathrm{C}$ to the $350^{\circ} \mathrm{C}$ isotherms without the transition zones). The resulting maximum downdip width obtained ranges from about $140 \mathrm{~km}$ (north of $16^{\circ} \mathrm{N}$ ) to $320 \mathrm{~km}$ at $13^{\circ} \mathrm{S}$ (measuring from the $100^{\circ} \mathrm{C}$ to the $450^{\circ} \mathrm{C}$ isotherms and thus including the transition zones). The hypocenters of thrust type earthquakes (only present for sections A-C) are projected as black diamonds and mostly fall between the $150^{\circ} \mathrm{C}$ and $350^{\circ} \mathrm{C}$ isotherms.

FIG. 6. - Structure thermique du domaine avant-arc obtenue par les modèles à éléments finis (isothermes tous les $100^{\circ} \mathrm{C}$ ) le long de six sections, avec indication des hypocentres (dans la zone délimitée en Fig. 1) et des limites de la zone sismogène prédites par les modèles thermiques. A) Antigua ; B) Guadeloupe ; C) Martinique NE-SW ; D) Martinique E-W ; E) Ste Lucie / Ride N Barbade, et F) St. Vincent / Barbade. La largeur minimale de la zone sismogène varie de $80 \mathrm{~km}$ (au nord de $16^{\circ} \mathrm{N}$ ) jusqu'à $230 \mathrm{~km}$ à $13^{\circ} \mathrm{S}$ (prenant la distance entre les isothermes de $150^{\circ} \mathrm{C}$ et $350^{\circ} \mathrm{C}$, sans inclure les zones de transition). Sa largeur maximale varie d'environ $140 \mathrm{~km}$ (au nord de $16^{\circ} \mathrm{N}$ ) jusqu'à $320 \mathrm{~km}$ à $13^{\circ} \mathrm{S}$ (prenant la distance entre les isothermes de $100^{\circ} \mathrm{C}$ et $450^{\circ} \mathrm{C}$, en incluant donc les zones de transition). Les hypocentres des séismes chevauchants (losanges noirs, sections A-C seulement) se localisent principalement entre les isothermes $150^{\circ} \mathrm{C}$ et $350^{\circ} \mathrm{C}$.

FIG. 7. - Observed surface heat flow (colored circles) and calculated surface heatflow for the six transects modeled. A) Antigua B) Guadeloupe, C) Martinique NE-SW, D) Martinique EW, E) St. Lucia / N Barbados Ridge and F) St. Vincent / Barbados. There are insufficient heat flow observations in the north to well constrain the thermal models. Few observations are available where heat flow increases going towards the arc due to the presence of the convecting mantle wedge. Two such critical data points at $15^{\circ} \mathrm{N}$ have been projected onto neighboring profiles B and E as well (green circles). Red circles are from the Global Heat Flow Database, from ODP Leg 110 (Fisher and Hounslow, 1990) and from a survey of the deformation front at $12^{\circ} 20^{\prime} \mathrm{N}$ (Foucher et al., 1990). Blue circles are from a detailed survey at $14^{\circ} 20^{\prime} \mathrm{N}$ (Langseth et al., 1990), with heat flow calculated from observations of the BSR (Bottom Simulating Reflector) shown by gray shading (Ferguson et al., 1993).

FIG. 7. - Comparaison du flux de chaleur mesuré (cercles colorés) et calculé pour les six sections étudiées. A) Antigua ; B) Guadeloupe ; C) Martinique NE-SW ; D) Martinique E-W ; E) Ste Lucie / Ride N Barbade, et F) St. Vincent / Barbade. Les mesures dans le nord de l'arc ne sont pas assez nombreuses pour permettre de contraindre les modèles. Seules deux mesures (cercles verts) obtenues à $15^{\circ} \mathrm{N}$ et montrées dans les sections adjacentes $B$ et $E$ suggèrent l'augmentation du flux de chaleur vers l'axe de l'arc (convection dans le coin de manteau). Source des données en cercles rouges : Global Heat Flow Database, d'après le Leg ODP 110 (Fisher et Hounslow, 1990) et l'étude du front de déformation à 12²0'N 
(Foucher et al., 1990). Source des données en cercles bleus : étude à 14²0'N (Langseth et al., 1990), avec le flux de chaleur calculé à partir des observations du BSR en ombré gris (Ferguson et al., 1993).

\section{Caption to Table I :}

TABLE IA. - General subduction parameter tests on the Guadeloupe transect, for subduction velocities of $1,2,3 \mathrm{~cm} / \mathrm{yr}$, slab ages of 60,80 and $100 \mathrm{Ma}$ and slab dips of $45^{\circ}$ and $57^{\circ}$. Table 1B : Position of isotherms along plate interface for each model tested.

TABL. IA. - Tests des paramètres généraux de la subduction au niveau de la Guadeloupe, pour des vitesses de subduction de 1, 2 et $3 \mathrm{~cm} / a n$, des âges de la plaque plongeante de 60, 80 et $100 \mathrm{Ma}$, et des pendages de $45^{\circ}$ et $57^{\circ}$ de celle-ci.

TABLE IB. - Position of isotherms along plate interface for each model tested.

TABL. IB. - Position des isothermes à l'interface des plaques pour chaque modèle testé. 

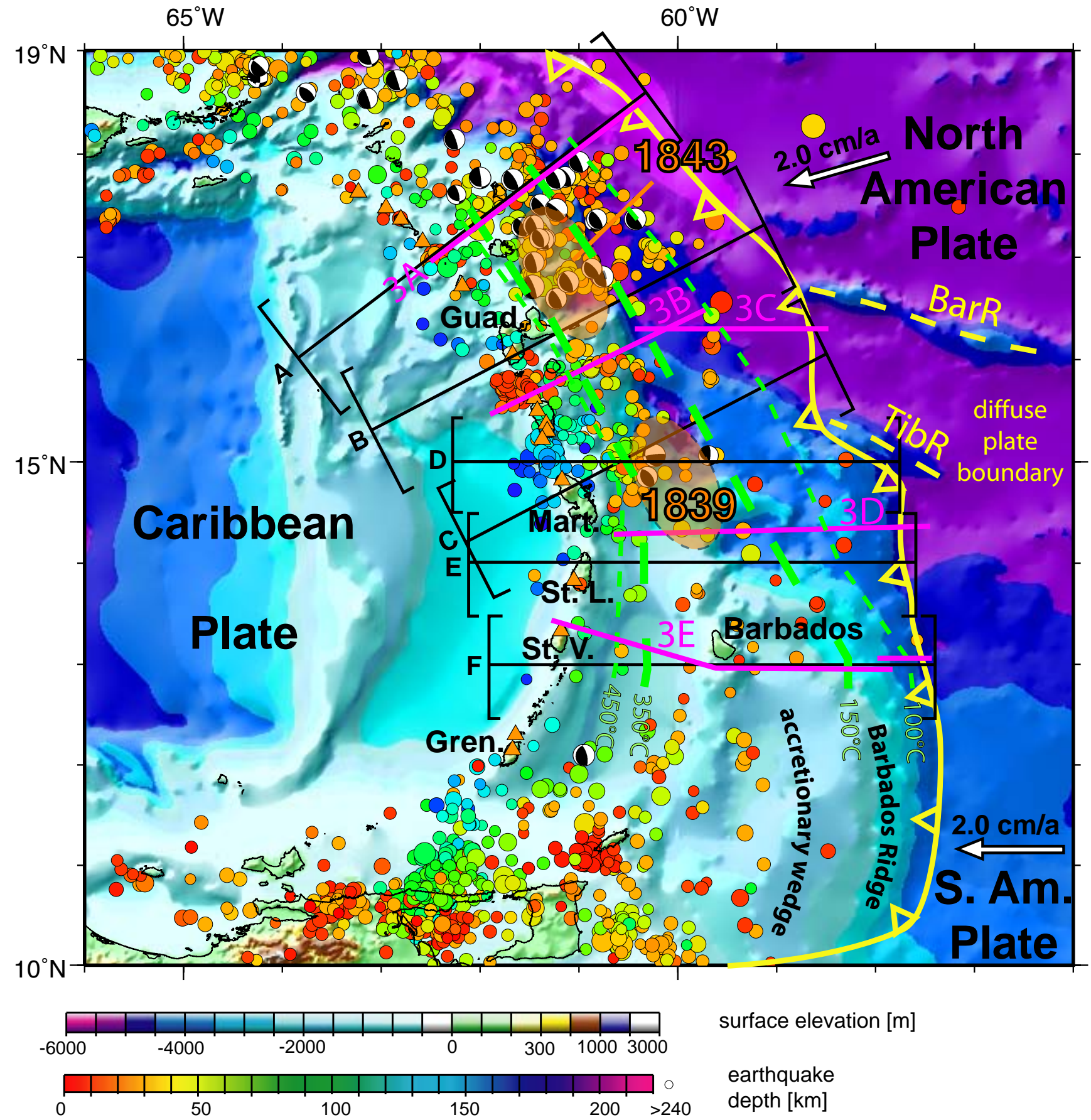


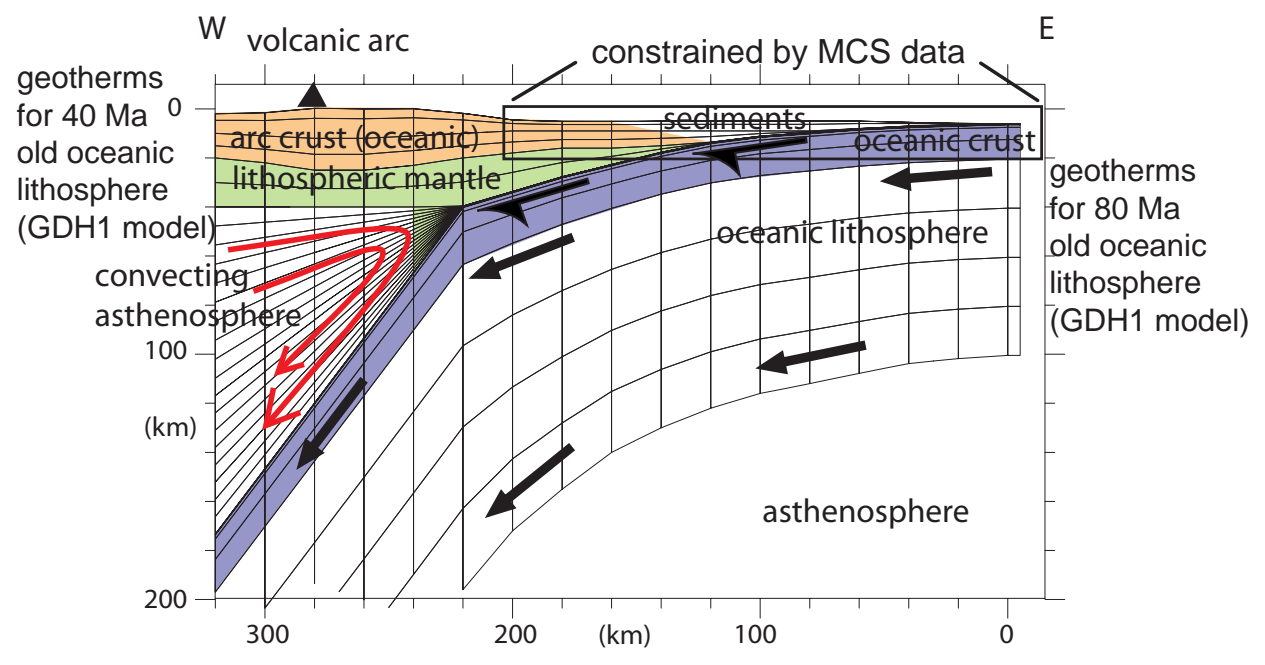


A) SW Antigua section (Westbrook \& McCann, 1986) NE
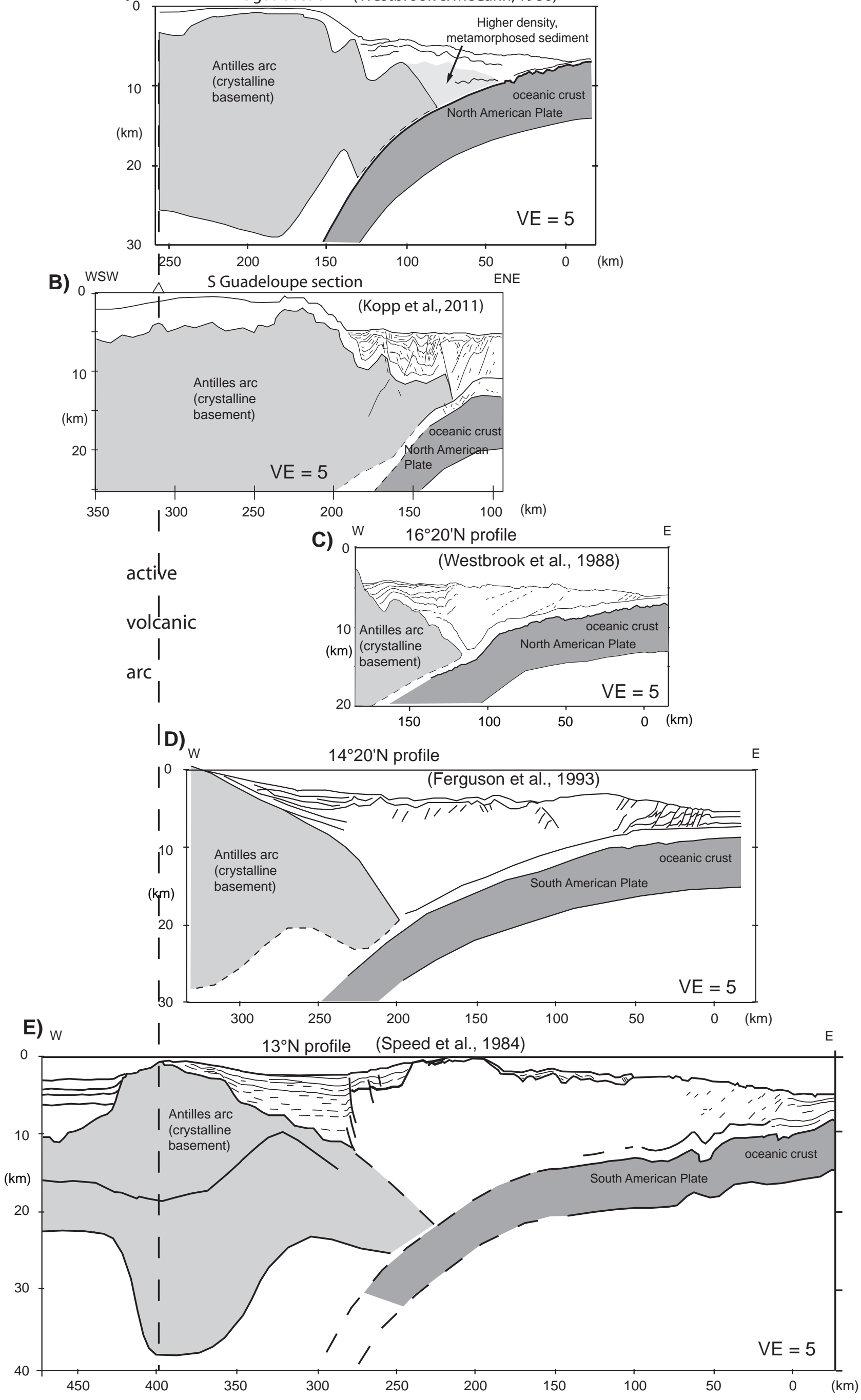


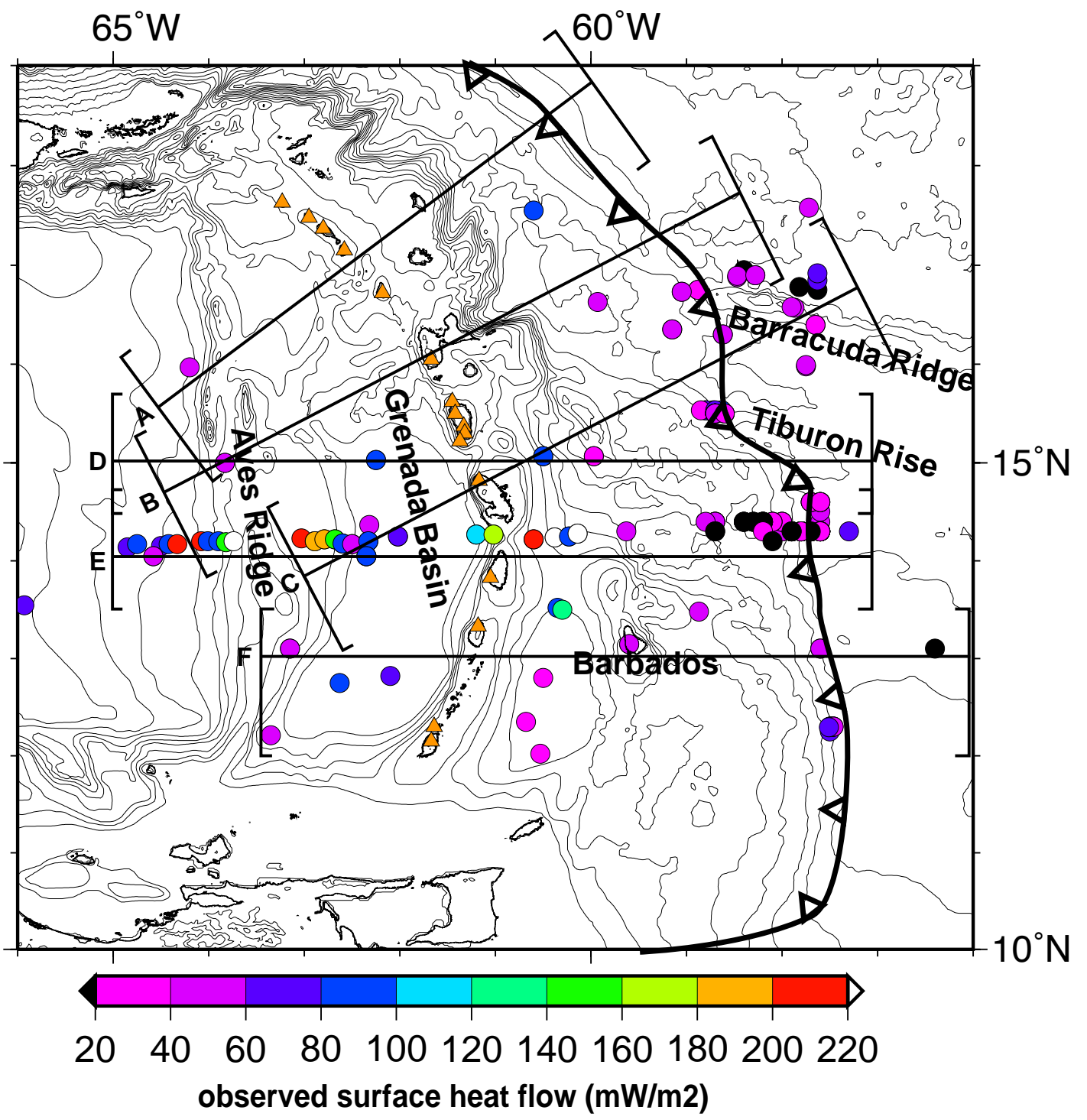



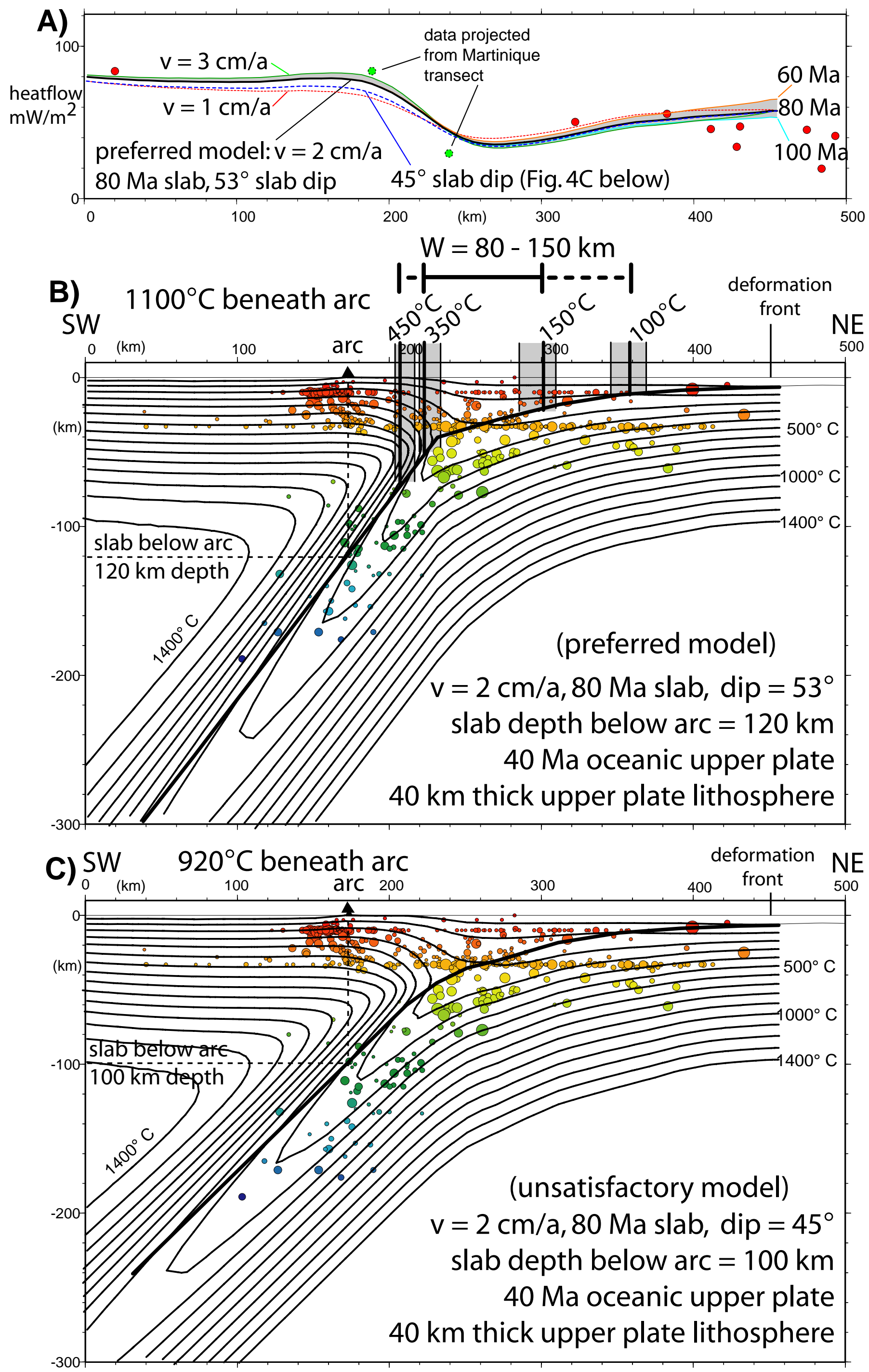

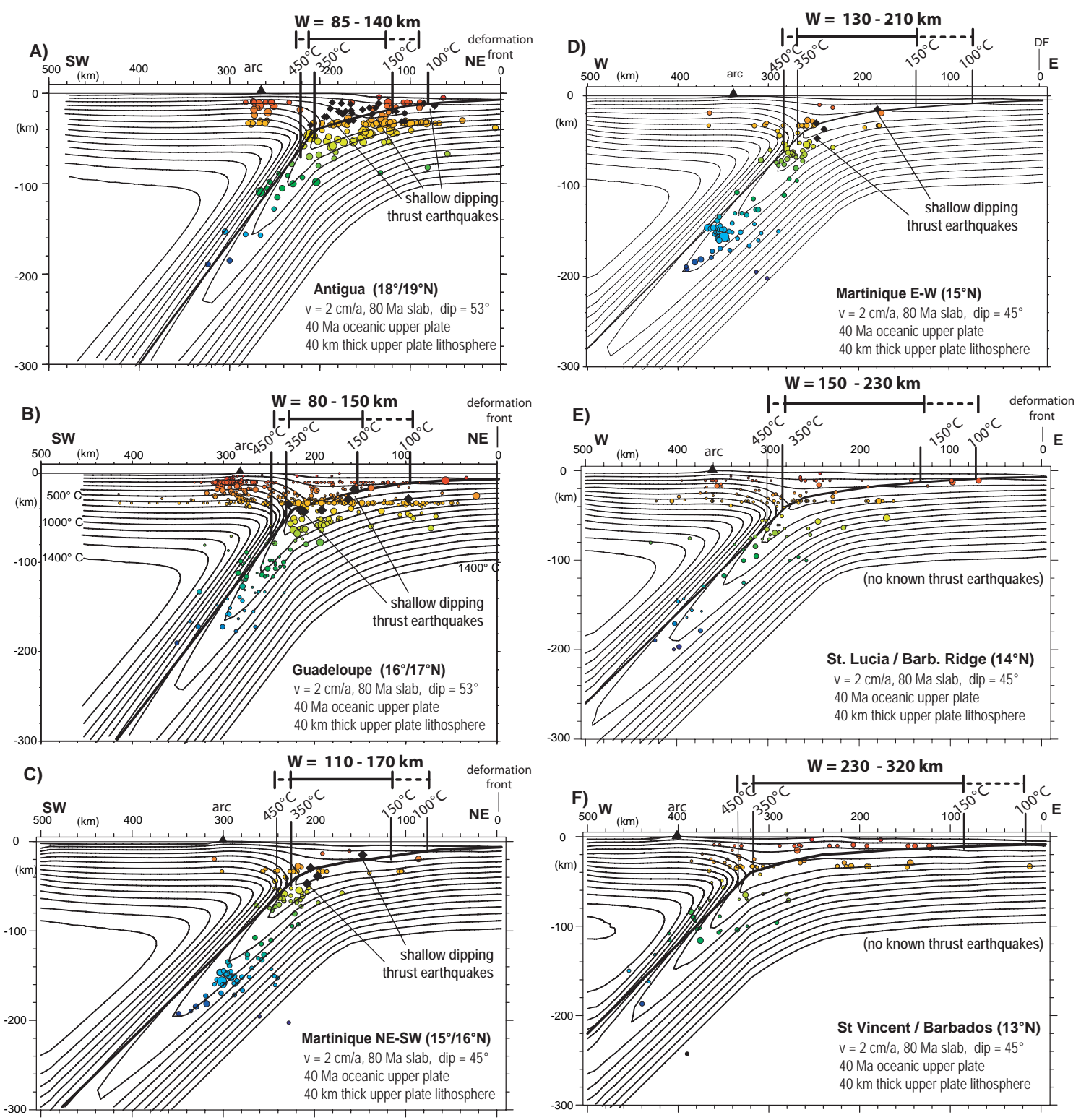


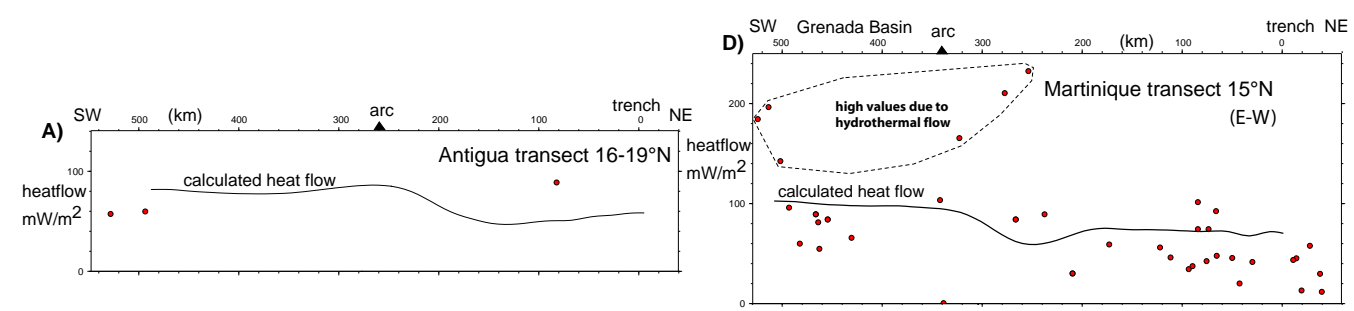

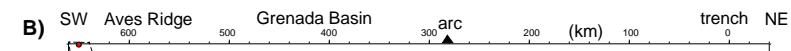
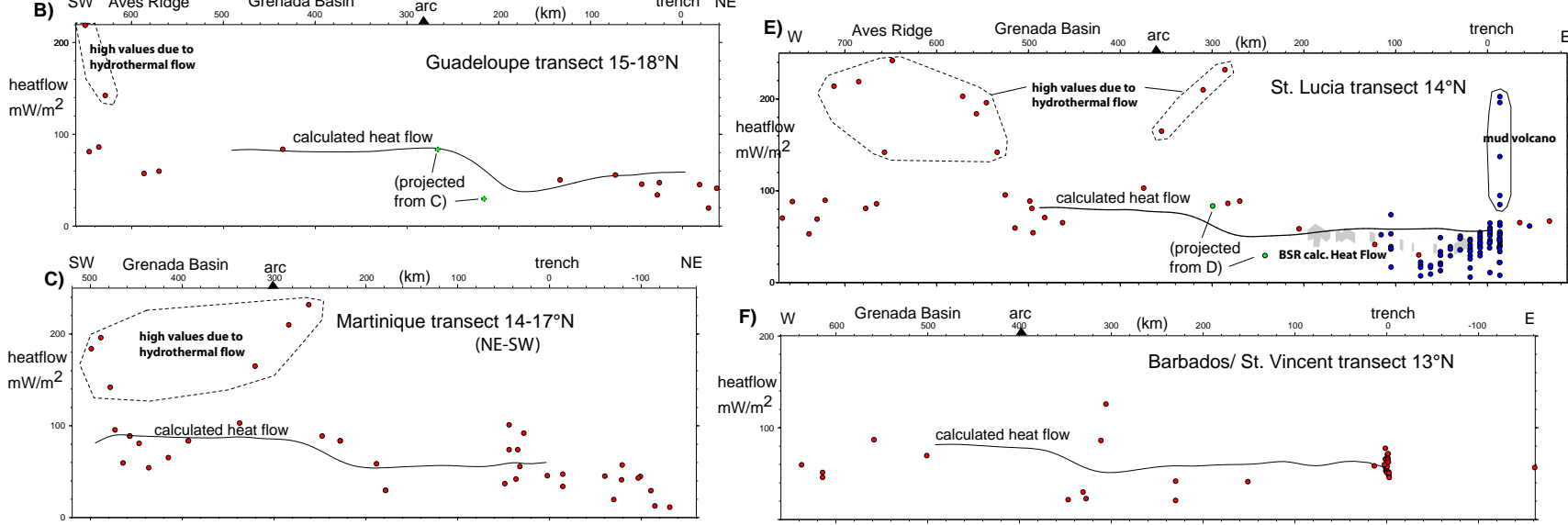
Table 1 A: General subduction parameter tests for Guadeloupe transect

\begin{tabular}{|l|l|l|l|}
\hline Parameter & min value & preferred value & max value \\
\hline Slab age & $60 \mathrm{Ma} \mathrm{(B)}$ & $80 \mathrm{Ma}(\mathrm{A})$ & $100 \mathrm{Ma}(\mathrm{C})$ \\
\hline Subduction velocity & $1 \mathrm{~cm} / \mathrm{a}(\mathrm{D})$ & $2 \mathrm{~cm} / \mathrm{a}(\mathrm{A})$ & $3 \mathrm{~cm} / \mathrm{a}(\mathrm{E})$ \\
\hline Dip angle (deep slab) & $45^{\circ}(\mathrm{F})$ & $53^{\circ}(\mathrm{A})$ & $53^{\circ} \quad(\mathrm{A})$ \\
\hline
\end{tabular}

Table $1 \mathrm{~B}$ : Position of isotherms at the interplate contact (distance from trench) and estimated temperature beneath the volcanic arc (Temp) for each tested model (the letters A-F represent the models described in Table 1A). "Bad" indicates model with unacceptably low temperatures beneath the arc.

\begin{tabular}{|l|l|l|l|l|}
\hline & $100^{\circ} \mathrm{C}$ & $150^{\circ} \mathrm{C}$ & $350^{\circ} \mathrm{C}$ & Temp \\
\hline Model tested & $\begin{array}{l}\text { distance from } \\
\text { trench }(\mathrm{km})\end{array}$ & $\begin{array}{l}\text { distance from } \\
\text { trench }(\mathrm{km})\end{array}$ & $\begin{array}{l}\text { distance from trench } \\
(\mathrm{km})\end{array}$ & \\
\hline A & 90 & 150 & $230(54 \mathrm{~km}$ deep $)$ & $1100^{\circ} \mathrm{C} \mathrm{ok}$ \\
\hline B & 85 & 145 & $225(50 \mathrm{~km}$ deep $)$ & $1090^{\circ} \mathrm{C}$ ok \\
\hline C & 100 & 155 & $225(50 \mathrm{~km}$ deep $)$ & $1090^{\circ} \mathrm{C}$ ok \\
\hline D & 85 & 135 & $230(54 \mathrm{~km}$ deep $)$ & $850^{\circ} \mathrm{C}(\mathrm{bad})$ \\
\hline E & 105 & 165 & $230(54 \mathrm{~km}$ deep $)$ & $1200^{\circ} \mathrm{C} \mathrm{ok}$ \\
\hline F & 90 & 155 & $230(54 \mathrm{~km}$ deep $)$ & $900^{\circ} \mathrm{C}(\mathrm{bad})$ \\
\hline
\end{tabular}

